\title{
Germ layer formation during Xenopus embryogenesis: the balance between pluripotency and differentiation
}

\author{
CAO Ying \\ Model Animal Research Center of Nanjing University and MOE Key Laboratory of Model Animals for Disease Study, Nanjing 210061, China \\ Received August 4, 2014; accepted December 30, 2014

\begin{abstract}
The African clawed frog, Xenopus laevis, has long been a model animal for the studies in the fields of animal cloning, developmental biology, biochemistry, cell biology, and physiology. With the aid of Xenopus, major molecular mechanisms that are involved in embryonic development have been understood. Germ layer formation is the first event of embryonic cellular differentiation, which is induced by a few key maternal factors and subsequently by zygotic signals. Meanwhile, another type of signals, the pluripotency factors in ES cells, which maintain the undifferentiated state, are also present during early embryonic cells. In this review, the functions of the pluripotency factors during Xenopus germ layer formation and the regulatory relationship between the signals that promote differentiation and pluripotency factors are discussed.
\end{abstract}

Xenopus, germ layer formation, pluripotency factors, ES cells

Citation: Cao Y. Germ layer formation during Xenopus embryogenesis: the balance between pluripotency and differentiation. Sci China Life Sci, 2015, 58: 336-342, doi: 10.1007/s11427-015-4799-2

The understanding of the process of embryonic development is not only a field of basic research. The underlying mechanisms also provide critical clues to the causes of many human diseases, for instances, congenital birth defects or cancers. Based on the studies on typical model animals using molecular and biochemical strategies during recent two or three decades, we can now understand roughly the key molecular events that underlie the framework of early embryonic development, e.g., germ layer induction, dorsoventral patterning, etc. Here I will summarize and discuss some research progress in germ layer formation during Xenopus embryogenesis, in particular the functions of pluripotency factors in controlling germ layer development.

\section{A brief introduction to Xenopus}

Among the few typical model animals, the African clawed

email: caoying@nju.edu.cn frog, Xenopus laevis, has made exceptional contributions to the study of embryonic development due to some favorable features: in vitro fertilization and development that make direct observation easier for early embryos, numerous eggs $(\sim 3,000$ eggs a female can give per spawning) with relatively big size (1.0-1.2 $\mathrm{mm}$ in diameter) that facilitates micromanipulation, and year-round egg laying in response to artificial hormonal stimulation that is in principle without seasonal limitation. Besides, the frog is an aquatic animal that is easy to keep in laboratories. In history, Xenopus was not used for the study on developmental biology at the beginning [1]. Instead, some other amphibian species such as the frog Rana, urodeles like the newt Triturus or axolotl Amblystoma, were used by the traditional experimental developmental biologists in Europe in the late 19th and early 20th centuries [1]. It was first introduced for endocrinological research. Because it can be stimulated to lay eggs in response to the hormone in the urine of a pregnant woman, it then in the 40th and 50th of the last century became widely used as a tool for pregnancy test in Europe and 
North America. This wide distribution made the animal readily accessible to researchers of developmental biology. However, the extensive application of Xenopus in developmental biology was believed to be due to an advantageous feature over urodeles, the big number of embryos that can satisfy the needs for cellular and biochemical experiments. Today, Xenopus can be found all over the world in the labs of developmental biology, biochemistry, cell biology, physiology, and so on. By taking the advantage of Xenopus, many influential achievements have been made towards the understanding of nuclear reprogramming [2], embryonic induction, pattern formation, and signaling pathways that regulate embryogenesis [3]. In 1958, John Gurdon [2] reported the cloning of Xenopus laevis via transferring the nuclei of mature intestinal cells into the enucleated oocytes. This pioneering work led to the cloning of Dolly the sheep and later on, the cloning of other numerous species of animals. The work also set up the concept of nuclear reprogramming, which can also be achieved by forced expression of a few transcription factors in differentiated cells [4] or by chemical treatment [5]. The molecular nature of embryonic induction and pattern formation had long been enigmatic until the 1990s, when the key genes such as noggin, chordin and cerberus were identified in Xenopus laevis [6,7]. The mesoderm induction properties of TGF $\beta$ and FGF signaling pathways were first characterized in Xenopus [8,9]. Besides developmental biology, Xenopus has been widely used for the research fields including biochemistry and physiology. For instances, the first eukaryotic translation and transcription-translation and electrophysiological study systems were established using Xenopus oocytes [3]. Albeit transgenic studies using Xenopus laevis have been rather successful [10-13], it is not a super model for genetic study because of its pseudotetraploidy and relatively long reproduction cycle. In this case, a diploid Xenopus species with much shorter reproduction cycle, Xenopus tropicalis, has entered the field $[14,15]$. The genome of Xenopus tropicalis was sequenced, while sequencing the genome of laevis is also underway $[16,17]$. With the development of new techniques such as zinc-finger nucleases (ZFNs), transcription activator-like effector nucleases (TALENs), and CRISPR/Cas, genome engineering has been also a routine work in Xenopus [18-22], as in mouse. Therefore, Xenopus can also serve as a non-mammalian model suitable for establishing disease models for human inherited diseases and performing drug discovery screening [23,24]. In the following, I will summarize some discoveries about the major signals that are involved in germ layer formation during Xenopus embryonic development.

\section{Germ layer formation in Xenopus laevis}

\subsection{Major signals that promote germ layer formation}

'It is not birth, marriage, or death, but gastrulation, which is truly the most important time in your life.' These words by Lewis Wolpert in 1986 stress the importance of the process of gastrulation during the development of an animal, although the events mentioned here are interdependent. Gastrulation is critical because the three germ layers, ectoderm, mesoderm and endoderm, are formed during the process that is accompanied with extensive cell migration. This is the first event of cellular differentiation after fertilization, which provides the prototype for the future body plan. Germ layers are formed in a strict spatiotemporal pattern within an embryo. In Xenopus, ectoderm is formed in the animal region of an embryo, while mesoderm locates in the equatorial region and endoderm is in the yolk-rich vegetal region (Figure 1A). Now we know that the nodal signaling pathway is the major signal for mesoderm and endoderm (combined as mesendoderm hereafter) induction in the embryonic development of all animals. However, during Xenopus germ layer formation, the Nodal signaling is initiated by the maternal transcriptional factor VegT. VegT is maternally transcribed and the transcript is localized to the vegetal pole of early cleavage and blastula embryos, and importantly, the encoded protein is required for zygotic transcription of nod$a l$-related genes and endoderm inducing genes [25-31]. $\beta$-catenin is another maternal factor that promotes germ layer formation. Its function is achieved, in cooperation with the DNA binding protein Tcf711/Tcf3 in the Tcf/Lef family, by stimulating the transcription of siamois in the dorso-vegetal cells of early blastula. siamois encodes a
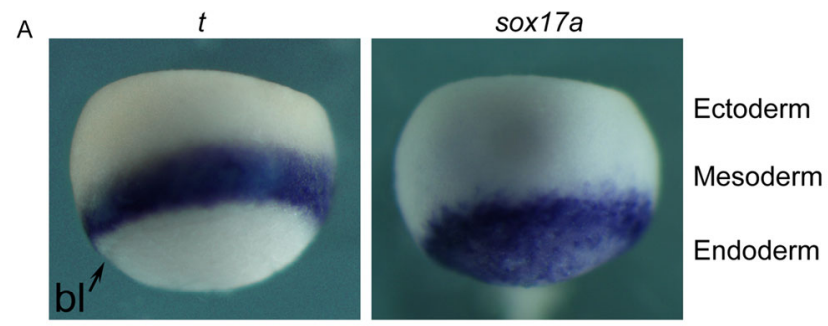

$B$

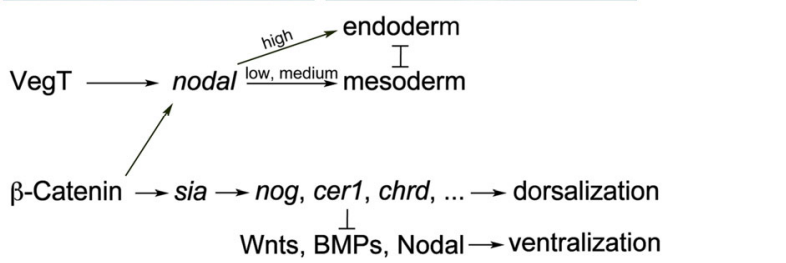

Figure 1 The spatial pattern and signals for germ layer formation in Xenopus gastrula embryos. A, The spatial pattern of three germ layers in Xenopus laevis gastrula embryo. In the left panel, the staining signal for the expression of the pan-mesodermal marker gene $t$ detected with whole mount in situ hybridization shows that mesoderm is formed in the equatorial region of embryo, while the region above (the animal region) is ectoderm. The slit-like structure indicated with an arrow is the dorsal blastopore lip (bl), the site of involution that drives morphogenetic movements during gastrulation. In the right panel, the expression of the endodermal marker gene $\operatorname{sox} 17 a$ indicates that the endoderm is formed in the vegetal region. In both panels, the embryos are shown with animal pole up and vegetal pole down, dorsal side to the left and the ventral side to the right. B, The signals that drive the induction and pattern formation of mesoderm and endoderm germ layers. Abbreviations: Cerl: Cerberus 1; chrd: chordin; nog: noggin; sia: siamois. See text for details. 
homeobox transcription factor that induces transcription of the genes encoding secreted proteins, such as Nog, Chrd, and Cer1, in the Spemann-Mangold organizer [32]. The secreted proteins function as antagonists against the Wnt, BMP and Nodal growth factors being emitted from the ventral side [32-36]. Moreover, $\beta$-catenin is able to boost transcription of nodal-related genes in the dorsal side of blastula and gastrula embryos, thus generating a decreasing nodal gradient along the dorsal-ventral axis [37,38]. Therefore, $\beta$-catenin plays a critical role in the establishment of dorsoventral axis. In the animal pole of early embryos, another maternal factor, Ectodermin, protects the animal region of blastula or gastrula embryos from the mesoderm-inducing signals, thus maintaining the identity of ectoderm in the animal region [39]. Figure 1B shows the model for germ layer induction and pattern formation.

\subsection{Pluripotency factors are expressed during Xenopus germ layer formation}

A fertilized egg is totipotent, because it can form a complete organism. After a few cycles of cleavage, a blastula is formed and the blastula ectoderm is competent to inducing factors like Activin to differentiate into cells of all three germ layers [40]. Therefore, these ectoderm cells exhibit the differentiation potential that resembles the mammalian pluripotent embryonic stem cells (ES cells). After mid-gastrula, the ectoderm cells gradually lose the competence to external inducing factor to form mesoderm or endoderm cells. This means that with the ongoing differentiation of embryonic cells, the differentiation potential of these cells decreases accordingly. Hence, it raises a question about correlation between the signals promoting differentiation and the signals regulating pluripotency.

As a branch of developmental biology, the study on ES cells has become increasingly popular due to the potential applications of ES cells in regenerative medicine. It is now clear that a few transcription factors, typically Pou5f1/Oct4, Sox2, Nanog, and Klf4, comprise a core regulatory circuitry for the regulation of pluripotency and self-renewal of ES cells [41]. Changes in the levels of these "pluripotency factors" in ES cells will cause the differentiation into lineage-specific cell types [42-44], suggesting that these factors are important in cell fate decision. Moreover, these factors can enable terminally differentiated cells to acquire pluripotency and self-renewal, which are the typical features of ES cells $[45,46]$. Nevertheless, the functions learned from the experiments with ES cells, which are cultured in concocted media, do not necessarily reflect the situation in whole embryos. Of the four pluripotency factors, the Oct4 homologous gene has been identified in Xenopus [47-51], zebrafish [52], Axolotl [53], and chicken [54]. A single Oct4 homologous gene exists in each of the animals except Xenopus, in which three homologous genes, oct 60 , oct 25 and oct 91 , are present in the genome [47-51], probably due to the duplication of chromosomes during evolution. The three Oct 4 homologous genes can be considered as a single one since they are arranged in a cluster, and moreover, the combined spatiotemporal expression pattern of the genes is equivalent to that of Oct4 in mouse. However, oct 91 among the three is the closest in expression and function to mammalian Oct4, because it is expressed in the germ line [55] as does mouse Oct4, whereas the other two are not. Meanwhile, Oct91 shows a better effect than Oct60 or Oct25 to rescue Oct4-null ES cells [51]. Sox2 and Klf4 genes are also well conserved in vertebrates, but the transcription during early stages of embryonic development differs somewhat. Whereas Sox 2 is transcribed both maternally and zygotically in mouse and Xenopus, Klf4 exhibits no maternal transcription in mouse [56] but displays both maternal and zygotic transcription in Xenopus [57]. Nanog homologous gene has been identified in zebrafish [58], axolotl [59] and chick [60], but not in Xenopus [16,58,61], suggesting that Nanog might be lost in the genus Xenopus.

\subsection{Regulation of germ layer formation by pluripoten- cy factors in Xenopus}

Many studies have demonstrated that the pluripotency factors are indispensable for the formation of germ layers. Among these factors, Oct4 has been shown to be involved in nearly every aspect of germ layer formation, including germ layer induction, dorsoventral patterning and cell migration. In Xenopus, Oct4 homologous proteins interfere the activities of maternal VegT and $\beta$-catenin, thus inhibiting the induction of mesendoderm [62]. Moreover, Xenopus Oct4 homologous factors mediate the zygotic events of mesendoderm formation, since these factors repress the function of Nodal/Activin signaling [63,64]. Besides, Oct25 and Oct91 are involved in the patterning of mesoderm and ectoderm $[50,65,66]$ at least partially via mediating the activity of BMP signaling $[50,66]$. In addition, Oct25 probably plays a role in the process of morphogenesis [67], the coordinated cell movement that shapes germ layers into a correct spatial arrangement. Sox 2 belongs to the B1 subgroup of Sox family of transcription factors that are well conserved in vertebrates. During Xenopus embryogenesis, sox2 is maternally expressed at a relatively low level, but its expression increases after mid-blastula transition and localizes specifically to the neuroectoderm during gastrulation and to the neural plates during neurulation. Hence, it is usually used as a marker gene for neuroectoderm. Sox 2 is not able to induce neural differentiation by itself in Xenopus ectoderm [68], but another study demonstrates that Sox2 alone can drive expression of neural genes [69]. Interestingly, the B1 subgroup Sox proteins repress VegT/ $\beta$-catenin stimulated nodal expression and $\mathrm{Wnt} / \beta$-catenin signaling [70-72]. Therefore, Sox 2 is similar to Oct4 homologous 
proteins in their functions in the inhibition of mesendoderm germ layer formation in Xenopus. From the studies above, we can conclude that during germ layer formation, there exists a delicate balance between the signals that maintain pluripotency of early embryonic cells and the signals that promote mesendoderm differentiation. The balance is achieved via at least partially the inhibitory effects of Oct4 homologous factors Oct60, Oct25 and Oct91 on the activities of maternal VegT, $\beta$-catenin and zygotic Nodal. If the activity of Oct 4 homologous factors is excessively high, then the early embryonic cells will remain in their undifferentiated state and germ layers will fail to differentiate. In contrast, if the activities of the signals that promote differentiation are too high, then germ layers will differentiate prematurely.

Although Nanog orthologous gene has not been identified in Xenopus, the work of two research groups suggests that vent1/2 (ventx) might play the functions of Nanog in Xenopus [58,61]. Vent1/2 were formerly shown as target genes of BMP signaling that mediates dorsoventral patterning. However, overexpression experiments by Schuff et al. [58] and Scerbo et al. [61] display that these genes regulate not only the patterning of dorsoventral axis, but also the differentiation of mesendoderm. In addition, overexpression of mouse Nanog (mNanog) or zebrafish Nanog (zNanog) in Xenopus embryos leads to a same phenotype as Vent1/2. In contrast, knockdown of Vent $1 / 2$ results in premature activation of differentiation genes, implying an effect of premature differentiation of early embryonic cells. It is not clear whether Vent1/2 employ similar molecular mechanisms to mediate cell differentiation, as do Oct 4 or Sox 2 homologous proteins. Among the pluripotency factors, Klf4 is quite different from the others in their functions regulating cell fate determination during germ layer formation. Gain of function analyses revealed that, contrary to the effect of gain of Oct4 or Sox 2 function, Klf4 promotes endoderm formation in both Nodal/Activin-dependent and -independent ways, and loss of function results in the failure of germ layer differentiation [57], an effect similar to gain of Oct4 or Sox2 function. Therefore, Klf4 displays an opposite effect on germ layer formation as compared with Oct4 or Sox 2, implying that the activity of different pluripotency factors should be also finely balanced to ensure correct germ layer formation. The functions of pluripotency factors during
Xenopus germ layer formation and their interaction with the major signals that promote germ layer formation are depicted in Figure 2.

Roles of pluripotency factors during zebrafish germ layer formation and mouse early development have also been investigated extensively. Some results are in well agreement with those for Xenopus, while others are in somewhat discrepancy. For example, gene knockouts demonstrate that Pou5f1/Oct4 and Sox 2 are both critical for pre-gastrula development in mice, while Klf4 just causes skin malfunction in newborn mice without defects in early embryos (Table 1). The situation might be explained either by the different experimental setups or by the functional complexity of these factors during embryogenesis. The complexity is reflected by the fact that an increasing number of additional factors, for example, Wdr5, esBAF, Ring1A/B, Zfp296, Nr5a2, Esrrb, integrate into the core circuitry and play a role in
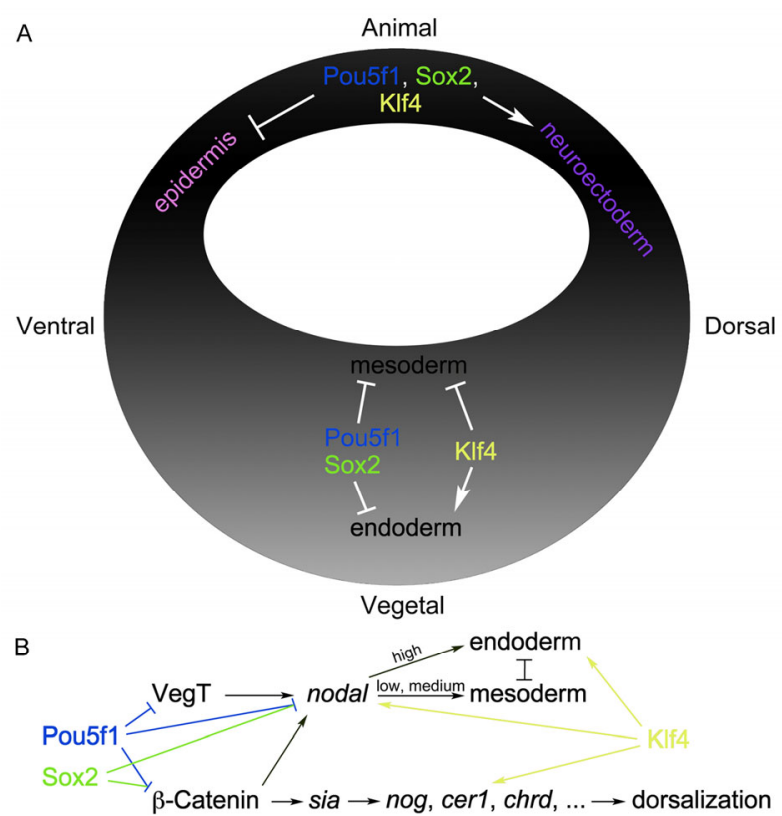

Figure 2 The functions of pluripotency factors during Xenopus embryogenesis and the underlying mechanisms. A, Pluripotency factors distributes ubiquitously in Xenopus early embryos. In ectoderm, they promote neuroectoderm while inhibit epidermal differentiation. In mesoderm and endoderm, both Pou5f1 and Sox2 exhibit an inhibitory effect. By contrast, Klf4 promotes endoderm differentiation. B, A diagram depicting the regulation of the signals that promote germ layer formation by pluripotency factors. See text for details.

Table 1 Comparison of the functions of pluripotency factors between Xenopus and mouse early embryonic development ${ }^{\text {a) }}$

\begin{tabular}{lll}
\hline & \multicolumn{1}{c}{ Xenopus } & \multicolumn{1}{c}{ Mouse $(-/-)^{*}$} \\
\hline Pou5f1 & $\begin{array}{l}\text { Gain of function represses mesoderm and endoderm formation but promotes neu- } \\
\text { ro-ectoderm differentiation. Loss of function leads to upregulation of mesoderm and } \\
\text { endoderm but downregulation of neural differentiation [50,51,62-66]. }\end{array}$ & $\begin{array}{l}\text { Perimplantation lethality prior to the egg cylinder } \\
\text { stage, failure to develop a pluripotent inner cell mass. }\end{array}$ \\
\hline Sox2 & $\begin{array}{l}\text { Gain of function upregulates neural differen-tiation and inhibits nodal signaling } \\
\text { [68-72]. }\end{array}$ & $\begin{array}{l}\text { Gain of function promotes endoderm and neuroectoderm differentiation and dorsaliz- } \\
\text { Klf4 body axis. Loss of function blocks germ layer differentiation [57]. }\end{array}$ \\
\hline
\end{tabular}

a) *, From the mouse database http://www.informatics.jax.org. 
regulating pluripotency and self-renewal. However, the roles of these factors in embryonic development have been largely unknown. Paradoxically, two latest reports elucidate that pluripotency factors Oct4, Nanog and SoxB1 are required for zygotic gene activation during zebrafish embryogenesis. When the functions of these factors are inhibited, most of zygotic genes fail to activate [73,74]. Zygotic gene activation is a prerequisite for cell differentiation after maternal store of transcripts have been degraded. Therefore, the so-called pluripotency factors are in fact a specialized term that is pertinent to ES cells only. In a different cellular environment, these factors may not just maintain the undifferentiated state of cells, but generate a precondition for cells to differentiate. This situation also holds true for the signals that promote germ layer differentiation in embryos, especially the Nodal and Wnt pathways. In ES cells, both pathways play important roles in the maintenance of pluripotency or self-renewal [75-78], which means that they maintain the undifferentiated state of cells. Therefore, the functions of a factor or a signaling pathway are dependent on the internal or external environment of cells. Those factors that play critical roles in ES cells should be important as well in the regulation of germ layer formation, and more experiments will perhaps elucidate some unexpected functions of these factors during embryogenesis.

This work was supported by the National Basic Research Program of China (2011CB943804, 2014CB964701) and the National Natural Science Foundation of China (31271544, 31261160492) to Cao Ying.

1 Gurdon JB, Hopwood N. The introduction of Xenopus laevis into developmental biology: of empire, pregnancy testing and ribosomal genes. Int J Dev Biol, 2000, 44: 43-50

2 Gurdon JB, Elsdale TR, Fischberg M. Sexually mature individuals of Xenopus laevis from the transplantation of single somatic nuclei. $\mathrm{Na}$ ture, 1958, 182: 64-65

3 Harland RM, Grainger RM. Xenopus research: metamorphosed by genetics and genomics. Trends Genet, 2011, 27: 507-515

4 Takahashi K, Yamanaka S. Induction of pluripotent stem cells from mouse embryonic and adult fibroblast cultures by defined factors. Cell, 2006, 126: 663-676

5 Hou P, Li Y, Zhang X, Liu C, Guan J, Li H, Zhao T, Ye J, Yang W, Liu K, Ge J, Xu J, Zhang Q, Zhao Y, Deng H. Pluripotent stem cells induced from mouse somatic cells by small-molecule compounds. Science, 2013, 341: 651-654

6 De Robertis EM. Spemann's organizer and self-regulation in amphibian embryos. Nat Rev Mol Cell Biol, 2006, 7: 296-302

7 Niehrs C. The Spemann organizer and the embryonic head induction. EMBO J, 2001, 20: 631-637

8 Smith JC. A mesoderm inducing factor is produced by a Xenopus cell line. Development, 1987, 99: 3-14

9 Slack JM, Darlington BG, Heath JK, Godsave SF. Mesoderm induction in early Xenopus embryos by heparin-binding growth factors. Nature, 1987, 326: 197-200

10 Allen BG, Weeks DL. Using phiC31 integrase to make transgenic Xenopus laevis embryos. Nat Protoc, 2006, 1: 1248-1257

11 Pan FC, Chen Y, Loeber J, Henningfeld K, Pieler T. I-SceI meganuclease-mediated transgenesis in Xenopus. Dev Dyn, 2006, 235 : 247-252

12 Chesneau A, Sachs LM, Chai N, Chen Y, Du Pasquier L, Loeber J,
Pollet N, Reilly M, Weeks D L, Bronchain OJ. Transgenesis procedures in Xenopus. Biol Cell, 2008, 100: 503-521

13 Takagi C1, Sakamaki K, Morita H, Hara Y, Suzuki M, Kinoshita N, Ueno N. Transgenic Xenopus laevis for live imaging in cell and developmental biology. Dev Growth Differ, 2013, 55: 422-433

14 Amaya E, Offield MF, Grainger RM. Frog genetics: Xenopus tropicalis jumps into the future. Trends Genet, 1998, 14: 253-255

15 Carruthers S, Stemple DL. Genetic and genomic prospects for Xenopus tropicalis research. Semin Cell Dev Biol, 2006, 17: 146-153

16 Hellsten U, Harland RM, Gilchrist MJ, Hendrix D, Jurka J, Kapitonov V, Ovcharenko I, Putnam NH, Shu S, Taher L, Blitz IL, Blumberg B, Dichmann DS, Dubchak I, Amaya E, Detter JC, Fletcher R, Gerhard DS, Goodstein D, Graves T, Grigoriev IV, Grimwood J, Kawashima T, Lindquist E, Lucas SM, Mead PE, Mitros T, Ogino H, Ohta Y, Poliakov AV, Pollet N, Robert J, Salamov A, Sater AK, Schmutz J, Terry A, Vize PD, Warren WC, Wells D, Wills A, Wilson RK, Zimmerman LB, Zorn AM, Grainger R, Grammer T, Khokha MK, Richardson PM, Rokhsar DS: The genome of the Western clawed frog Xenopus tropicalis. Science, 2010, 328: 633-636

17 James-Zorn C, Ponferrada VG, Jarabek CJ, Burns KA, Segerdell EJ, Lee J, Snyder K, Bhattacharyya B, Karpinka JB, Fortriede J, Bowes JB, Zorn AM, Vize PD. Xenbase: expansion and updates of the Xenopus model organism database. Nucleic Acids Res, 2013, doi: 10.1093/nar/gks1025

18 Young JJ, Cherone JM, Doyon Y, Ankoudinova I, Faraji FM, Lee AH, Ngo C, Guschin DY, Paschon DE, Miller JC, Zhang L, Rebar EJ, Gregory PD, Urnov FD, Harland RM, Zeitler B. Efficient targeted gene disruption in the soma and germ line of the frog Xenopus tropicalis using engineered zinc-finger nucleases. Proc Natl Acad Sci USA, 2011, 108: 7052-7057

19 Lei Y, Guo X, Liu Y, Cao Y, Deng Y, Chen X, Cheng CH, Dawid IB, Chen Y, Zhao H. Efficient targeted gene disruption in Xenopus embryos using engineered transcription activator-like effector nucleases (TALENs). Proc Natl Acad Sci USA, 2012, 109: 17484-17489

20 Nakajima K, Nakajima T, Takase M, Yaoita Y. Generation of albino Xenopus tropicalis using zinc-finger nucleases. Dev Growth Differ, 2012, 54: 777-784

21 Nakajima K, Nakai Y, Okada M, Yaoita Y. Targeted gene disruption in the Xenopus tropicalis genome using designed TALE nucleases. Zoolog Sci, 2013, 30: 455-460

22 Guo X, Zhang T, Hu Z, Zhang Y, Shi Z, Wang Q, Cui Y, Wang F, Zhao H, Chen Y. Efficient RNA/Cas9-mediated genome editing in Xenopus tropicalis. Development, 2014, 141: 707-714

23 Wheeler GN, Brändli AW. Simple vertebrate models for chemical genetics and drug discovery screens: lessons from zebrafish and Xenopus. Dev Dyn, 2009, 238: 1287-1308

24 Schmitt SM, Gull M, Brändli AW. Engineering Xenopus embryos for phenotypic drug discovery screening. Adv Drug Deliv Rev, 2014, 69-70: 225-246

25 Zhang J, Houston DW, King ML, Payne C, Wylie C, Heasman J. The role of maternal $\mathrm{VegT}$ in establishing the primary germ layers in Xenopus embryos. Cell, 1998, 94: 515-524

26 Clements D, Friday RV, Woodland HR. Mode of action of VegT in mesoderm and endoderm formation. Development, 1999, 126: 4903-4911

27 Kofron M, Demel T, Xanthos J, Lohr J, Sun B, Sive H, Osada S, Wright C, Wylie C, Heasman J. Mesoderm induction in Xenopus is a zygotic event regulated by maternal VegT via TGFbeta growth factors. Development, 1999, 126: 5759-5770

28 Hyde CE, Old RW. Regulation of the early expression of the Xenopus nodal-related 1 gene, Xnr1. Development, 2000, 127: 1221-1229

29 Xanthos JB, Kofron M, Wylie C, Heasman J. Maternal VegT is the initiator of a molecular network specifying endoderm in Xenopus laevis. Development, 2001, 128: 167-180

30 White RJ, Sun BI, Sive HL, Smith JC. Direct and indirect regulation of derriere, a Xenopus mesoderm-inducing factor, by VegT. Development, 2002, 129: 4867-4876 
31 Shivdasani RA. Molecular regulation of vertebrate early endoderm development. Dev Biol, 2002, 249: 191-203

32 De Robertis EM, Larraín J, Oelgeschläger M, Wessely O. The establishment of Spemann's organizer and patterning of the vertebrate embryo. Nat Rev Genet, 2000, 1: 171-181

33 Behrens J, von Kries JP, Ku“hl M, Bruhn L, Wedlich D, Grosschedl $\mathrm{R}$, Birchmeier W. Functional interaction of beta-Catenin with the transcription factor LEF-1. Nature, 1996, 382: 638-642

34 Harland R, Gerhart J. Formation and function of Spemann's organizer. Annu Rev Cell Dev Biol, 1997, 13: 611-667

35 Wodarz A, Nusse R. Mechanisms of Wnt signaling in development. Annu Rev Cell Dev Biol, 1998, 14: 59-88

36 Wessely O, Agius E, Oelgeschlager M, Pera EM, DeRobertis EM. Neural induction in the absence of mesoderm: $\beta$-Catenin dependent expression of secreted BMP antagonists at the blastula stage in Xenopus. Dev Biol, 2001, 234: 161-173

37 Agius E, Oelgeschlager M, Wessely O, Kemp C, De Robertis EM. Endodermal nodal-related signals and mesoderm induction in Xenopus. Development, 2000, 127: 1173-1183

38 Takahashi S, Yokota C, Takano K, Tanegashima K, Onuma Y, Goto J, Asashima M. Two novel nodal-related genes initiate early inductive events in Xenopus Nieuwkoop center. Development, 2000, 127: 5319-5329

39 Dupont S, Zacchigna L, Cordenonsi M, Soligo S, Adorno M, Rugge M, Piccolo S. Germ-layer specification and control of cell growth by Ectodermin, a Smad4 ubiquitin ligase. Cell, 2005, 121: 87-99

40 Okabayashi K, Asashima M. Tissue generation from amphibian animal caps. Curr Opin Genet Dev, 2003, 13: 502-507

41 Boyer LA, Lee TI, Cole MF, Johnstone SE, Levine SS, Zucker JP, Guenther MG, Kumar RM, Murray HL, Jenner RG, Gifford DK, Melton DA, Jaenisch R, Young RA. Core transcriptional regulatory circuitry in human embryonic stem cells. Cell, 2005, 122: 947-956

42 Niwa H, Miyazaki J, Smith AG. Quantitative expression of Oct-3/4 defines differentiation, dedifferentiation or self-renewal of ES cells. Nat Genet, 2000, 24: 372-376

43 Hay DC, Sutherland L, Clark J, Burdon T. Oct-4 knockdown induces similar patterns of endoderm and trophoblast differentiation markers in human and mouse embryonic stem cells. Stem Cells, 2004, 22: 225-235

44 Li J, Pan G, Cui K, Liu Y, Xu S, Pei D. A dominant-negative form of mouse SOX2 induces trophectoderm differentiation and progressive polyploidy in mouse embryonic stem cells. J Biol Chem, 2007, 282: 19481-19492

45 Takahashi K, Yamanaka S. Induction of pluripotent stem cells from mouse embryonic and adult fibroblast cultures by defined factors. Cell, 2006, 126: 663-676

46 Yu J, Vodyanik MA, Smuga-Otto K, Antosiewicz-Bourget J, Frane JL, Tian S, Nie J, Jonsdottir GA, Ruotti V, Stewart R, Slukvin II, Thomson JA. Induced pluripotent stem cell lines derived from human somatic cells. Science, 2007, 318: 1917-1920

47 Hinkley CS, Martin JF, Leibham D, Perry M. Sequential expression of multiple POU proteins during amphibian early development. Mol Cell Biol, 1992, 12: 638-649

48 Whitfield T, Heasman J, Wylie C. XLPOU-60, a Xenopus POU domain mRNA, is oocyte-specific from very early stages of oogenesis, and localised to presumptive mesoderm and ectoderm in the blastula. Dev Biol, 1993, 155: 361-370

49 Whitfield TT, Heasman J, Wylie CC. Early embryonic expression of XLPOU-60, a Xenopus POU-domain protein. Dev Biol, 1995, 169: 759-769

50 Cao Y, Knöchel S, Donow C, Miethe J, Kaufmann E, Knöchel W. The POU factor Oct-25 regulates the Xvent-2B gene and counteracts terminal differentiation in Xenopus embryos. J Biol Chem, 2004, 279: 43735-43743

51 Morrison GM, Brickman JM. Conserved roles for Oct4 homologues in maintaining multipotency during early vertebrate development. Development, 2006, 133: 2011-2022

52 Burgess S, Reim G, Chen W, Hopkins N, Brand M. The zebrafish spiel-ohne-grenzen (spg) gene encodes the POU domain protein Pou2 related to mammalian Oct4 and is essential for formation of the midbrain and hindbrain, and for pre-gastrula morphogenesis. Development, 2002, 129: 905-916

53 Bachvarova RF, Masi T, Drum M, Parker N, Mason K, Patient R, Johnson AD. Gene expression in the axolotl germ line: Axdazl, Axvh, Axoct-4, and Axkit. Dev Dyn, 2004, 231: 871-880

54 Lavial F, Acloque H, Bertocchini F, Macleod DJ, Boast S, Bachelard E, Montillet G, Thenot S, Sang HM, Stern CD, Samarut J, Pain B. The Oct4 homologue PouV and Nanog regulate pluripotency in chicken embryonic stem cells. Development, 2007, 134: 3549-3563

55 Venkatarama T, Lai F, Luo X, Zhou Y, Newman K, King ML. Repression of zygotic gene expression in the Xenopus germline. Development, 2010, 137: 651-660

56 Ehlermann J, Pfisterer P, Schorle H. Dynamic expression of Krüppel-like factor 4 (Klf4), a target of transcription factor AP2alpha during murine mid-embryogenesis. Anat Rec A Discov Mol Cell Evol Biol, 2003, 273: 677-680

57 Cao Q, Zhang X, Lu L, Yang L, Gao J, Gao Y, Ma H, Cao Y. Klf4 is required for germ-layer differentiation and body axis patterning during Xenopus embryogenesis. Development, 2012, 139: 3950-3961

58 Schuff M, Siegel D, Philipp M, Bundschu K, Heymann N, Donow C, Knöchel W. Characterization of Danio rerio Nanog and functional comparison to Xenopus Vents. Stem Cells Dev, 2012, 21: 1225-1238

59 Dixon JE, Allegrucci C, Redwood C, Kump K, Bian Y, Chatfield J, Chen YH, Sottile V, Voss SR, Alberio R, Johnson AD. Axolotl Nanog activity in mouse embryonic stem cells demonstrates that ground state pluripotency is conserved from urodele amphibians to mammals. Development, 2010, 137: 2973-2980

60 Cañón S, Herranz C, Manzanares M. Germ cell restricted expression of chick Nanog. Dev Dyn, 2006, 235: 2889-2894

61 Scerbo P, Girardot F, Vivien C, Markov GV, Luxardi G, Demeneix B, Kodjabachian L, Coen L. Ventx factors function as nanog-like guardians of developmental potential in xenopus. PLoS One, 2012, 7 : e36855

62 Cao Y, Siegel D, Donow C, Knöchel S, Yuan L, Knöchel W. POU-V factors antagonize maternal VegT activity and $\beta$-Catenin signaling in Xenopus embryos. EMBO J, 2007, 26: 2942-2954

63 Cao Y, Siegel D, Knöchel W. Xenopus POU factors of subclass V inhibit activin/nodal signaling during gastrulation. Mech Dev, 2006, 123: 614-625

64 Cao Y, Siegel D, Oswald F, Knöchel W. Oct25 represses transcription of nodal/activin target genes by interaction with signal transducers during Xenopus gastrulation. J Biol Chem, 2008, 283: 34168-34177

65 Snir M, Ofir R, Elias S, Frank D. Xenopus laevis POU91 protein, an Oct3/4 homologue, regulates competence transitions from mesoderm to neural cell fates. EMBO J, 2006, 25: 3664-3674

66 Takebayashi-Suzuki K, Arita N, Murasaki E, Suzuki A. The Xenopus POU class V transcription factor XOct-25 inhibits ectodermal competence to respond to bone morphogenetic protein-mediated embryonic induction. Mech Dev, 2007, 124: 840-855

67 Julier A, Goll C, Korte B, Knöchel W, Wacker SA. Pou-V factor Oct25 regulates early morphogenesis in Xenopus laevis. Dev Growth Differ, 2012, 54: 702-716

68 Mizuseki K, Kishi M, Matsui M, Nakanishi S, Sasai Y. Xenopus Zic-related-1 and Sox-2, two factors induced by chordin, have distinct activities in the initiation of neural induction. Development, 1998, 125: 579-587

69 Archer TC, Jin J, Casey ES. Interaction of Sox1, Sox2, Sox3 and Oct4 during primary neurogenesis. Dev Biol, 2011, 350: 429-440

70 Zorn, AM, Barish, GD, Williams, BO, Lavender, P, Klymkowsky, MW, Varmus, HE. Regulation of Wnt signaling by Sox proteins: XSox $17 \mathrm{a} / \mathrm{h}$ and XSox3 physically interact with h-catenin. Mol Cell, 1999, 4: 487-498

71 Zhang, C, Basta, T, Jensen, ED, Klymkowsky, MW. The b-catenin/VegT-regulated early zygotic gene Xnr5 is a direct target of SOX3 regulation in Xenopus. Development, 2003, 130: 5609-5624

72 Zhang C, Basta T, Hernandez-Lagunas L, Simpson P, Stemple DL, Artinger KB, Klymkowsky MW. Repression of nodal expression by 
maternal B1-type SOXs regulates germ layer formation in Xenopus and zebrafish. Dev Biol, 2004, 273: 23-37

73 Leichsenring M, Maes J, Mössner R, Driever W, Onichtchouk D. Pou5f1 transcription factor controls zygotic gene activation in vertebrates. Science, 2013, 341: 1005-1009

74 Lee MT, Bonneau AR, Takacs CM, Bazzini AA, DiVito KR, Fleming ES, Giraldez AJ. Nanog, Pou5f1 and SoxB1 activate zygotic gene expression during the maternal-to-zygotic transition. Nature, 2013, 503: $360-364$

75 James D, Levine AJ, Besser D, Hemmati-Brivanlou A. TGFbeta/activin/nodal signaling is necessary for the maintenance of plu- ripotency in human embryonic stem cells. Development, 2005, 132: 1273-1282

76 Vallier L, Alexander M, Pedersen RA. Activin/Nodal and FGF pathways cooperate to maintain pluripotency of human embryonic stem cells. J Cell Sci, 2005, 118: 4495-4509

77 Sato N, Meijer L, Skaltsounis L, Greengard P, Brivanlou AH. Maintenance of pluripotency in human and mouse embryonic stem cells through activation of Wnt signaling by a pharmacological GSK-3-specific inhibitor. Nat Med, 2004, 10: 55-63

78 Sokol SY. Maintaining embryonic stem cell pluripotency with Wnt signaling. Development, 2011, 138: 4341-4350

Open Access This article is distributed under the terms of the Creative Commons Attribution License which permits any use, distribution, and reproduction in any medium, provided the original author(s) and source are credited. 